\title{
Wilson France: a national database for Wilson's disease
}

\author{
Jean-Marc Trocello \\ From 5th European Conference on Rare Diseases (ECRD 2010) \\ Krakow, Poland. 13-15 May 2010
}

\section{Introduction}

Wilson's disease (WD) is a rare inherited disease with an efficient treatment if initiated early. Improving the knowledge of this disease is a priority of the French national Centre of Expertise for a better access to diagnosis and treatment. This national organisation created a database.

\section{Objective}

Improve the knowledge of WD by an epidemiological study on the French cohort.

\section{Methods}

We registered all patients followed by all the French centres working with the national Centre of Expertise.

\section{Results}

Since 2006, 281 patients (1-73 year old) were included in the Wilson France database (sex ratio: 1). Mean age at diagnosis was 19 years. First symptoms were neurological for $36 \%$ of the patients, hepatic for $38 \%$, renal, psychiatric or hematologic for $11 \%$. Fifteen percent were diagnosed after familial screening. At time of diagnosis, Kayser-Fleischer ring was observed in $95 \%$ of patients with neurological symptoms, in $55 \%$ of hepatic presentations and in $26 \%$ of the presymptomatic forms. Mean coeruloplasminemia was low $(0.08 \mathrm{~g} / \mathrm{L})$ but $5 \%$ of patients had normal values $(>0.2 \mathrm{~g} / \mathrm{L})$. Mean urinary copper was increased in $96 \%$ of the patients. Genetic investigation was not conclusive in $15.9 \%$ of the families (only one or no mutation found). First treatment was D-Penicillamine in $85 \%$ of the cases and after a mean follow up of 15 years, the treatment was D-Penicillamine for $44.4 \%$ of the patients, Trientine for $14.4 \%$,

Correspondence: cnr.wilson@lrb.aphp.fr

Centre National de Référence Wilson, Hôpital Lariboisière, 75475 Paris, France
Zinc for $26.7 \%$, association of chelator and zinc for 5.6 $\%$; $5.6 \%$ of the patients had liver transplantation.

\section{Discussion}

The database included approximately $1 / 3$ of the Wilson disease patients in France. In order to improve the recruitment of Wilson's disease patients, coordination of all health professionals with a multidisciplinary approach is necessary. This work is realised in collaboration with Eurowilson database.

Published: 19 October 2010

doi:10.1186/1750-1172-5-S1-P21

Cite this article as: Trocello: Wilson France: a national database for

Wilson's disease. Orphanet Journal of Rare Diseases 2010 5(Suppl 1):P21.

Submit your next manuscript to BioMed Central and take full advantage of:

- Convenient online submission

- Thorough peer review

- No space constraints or color figure charges

- Immediate publication on acceptance

- Inclusion in PubMed, CAS, Scopus and Google Scholar

- Research which is freely available for redistribution

Submit your manuscript at www.biomedcentral.com/submit 